ISSN 2080-1653

DOI 10.24917/20801653.324.5

TOMASZ RACHWAE

Pedagogical University of Cracow, Poland

\title{
Research Issues of Structural Changes in Polish Industry in Geography of Industry
}

\begin{abstract}
The research themes of geography of industry are continually evolving. The dynamic development of this sector of the economy after 1945 in the conditions of the socialist economy, in which the processes of industrialisation of the country were treated as priorities, as well as the processes of economic transformation in Poland after 1989, influencing the changes in the previously developed socio-economic structures, including industry structures, influenced the shaping of the research problem of this sub-discipline of geography in Poland. These changes, leading to the adaptation of these structures to the changing management principles, take place under the influence of impulses from the international environment associated with building a knowledge-based economy and moving from the industrial and post-industrial phase to the informational phase of civilisation development. These essential issues of transformation of industrial structures in the period of economic transformation and the development of a knowledge-based economy have become the subject of interest of many researchers, including economic geographers. The article presents the evolution of the themes and the main directions of research on structural changes in Polish industry in the conditions of transition from the centrally planned economy to market economy. In conclusion, it is shown that Polish geography of industry has undertaken significant scientific and economic problems of structural changes in industry during the period of economic transformation, continually updating its research priorities. Researchers quickly reacted to changes in the legal and political conditions of the functioning of the national economy, despite numerous barriers, related to, among other things, limited access to data on industrial activities, resulting in the lower interest of geographers in industrial research. The paper ends with recommendations regarding future possible research directions and a comprehensive bibliography of the studies.
\end{abstract}

Keywords: industrial change; industrial geography; Polish industry; research issues in industrial geography

Received: 1 March 2018

Accepted: 28 September 2018

\section{Suggested citation:}

Rachwał, T. (2018). Research Issues of Structural Changes in Polish Industry in Geography of Industry. Prace Komisji Geografii Przemysłu Polskiego Towarzystwa Geograficznego [Studies of the Industrial Geography Commission of the Polish Geographical Society], 32(4), 86-109. https://doi.org/10.24917/20801653.324.5 


\section{INTRODUCTION}

Research issues of geography of industry have been continuously evolving, which is reflected in the changing research directions. Growing scientific achievements, based on the results of many empirical studies, requires further syntheses to identify changing research problems and directions, learn about the patterns in development of industrial enterprises, spatial forms of industry concentration, industrial regional, national, European and global systems, as well as changes in the spatial and branch structure of industry.

The development of this sector of the economy after World War II in the conditions of central economic planning, referred to as the socialist or command-and-distribution economy, as well as the processes of economic transformation in Poland after 1989, which took place in the conditions of globalisation and European integration, affecting the transformation of previously developed socio-economic structures, including industry ones, had a particular impact on the development of research in this sub-discipline in Poland. These changes, leading to the adaptation of these structures to the changing management principles, take place under the influence of impulses from the international environment associated with building a knowledge-based economy and moving from the industrial and post-industrial phase to the informational phase of civilisation development. Their effect are changes in the sectoral structure of the economy, in which industrial activity, being the economic base in the industrial phase, gives way to service activities, in particular, activities related to financial services, education, science, as well as research and development. However, it should be emphasised that this reduction in the role of industry in favour of services mainly concerns the activation of labour resources, not its significance in the development of civilisation. The consequence of this process is the change of the existing spatial and branch structures of industry and its functions in the economic development of spatial systems of various scales, from local systems, through regional to national and international.

These crucial problems of changes of industrial structures in the period of economic transformation and the development of a knowledge-based economy have become the subject of interest of many researchers, representatives of various scientific disciplines, including economic geographers. A particular role was played by the studies undertaken in the field of geography of industry, which during the period of dynamic changes in the role of industrial activity in the economy, industrial policy directions, and changes in the accessibility of data on production activities, had to analyse its previous achievements and undertake new research issues, in accordance with the emerging challenges, both in methodological terms and in terms of business practice. After all, these studies have always served not only theoretical-cognitive but also application-oriented goals, supporting the formulation of strategic goals in the field of directions of economic transformation and changes in industrial policy. It should also be noted that the interest in research in the field of geography of industry, as well as the scope and direction of undertaken studies, was influenced mainly by changes in the availability of industrial statistics, in particular restrictions on the availability of unit data on the functioning of individual industrial enterprises.

The aim of the article is, therefore, to attempt to outline changes in the field of scientific interests of Polish geographers of industry, to identify the main research fields and related significant achievements, both cognitive and in the application of new 
methods of research of structural changes in Polish industry. It will be aimed at answering the question of the extent to which the new research issues in the field of geography of industry are part of the current research and application priorities of Polish science. Particular emphasis will be put on research problems undertaken during the period of intense changes related to systemic transformation in Poland in the last nearly three decades connected with the transition from the centrally controlled economy to market-based economy.

To this end, analyses of over 200 articles in various journals and monographic publications related to the development of research issues of Polish geography of industry in the field of transformation of this sector in Poland were carried out. This work was primarily presented at conferences on geography of industry organised every year in Krakow (Rachwał, 2015a) and published, especially in the last 18 years, in the "Studies of the Industrial Geography Commission of the Polish Geographical Society" (Polish title: Prace Komisji Geografii Przemysłu Polskiego Towarzystwa Geograficznego), as well as other leading journals and publishing series, both national and foreign. Based on the analysis of previous studies, an attempt was made to outline new challenges and possible directions of research that could be taken up by geographers of industry in Poland. Due to the vastness of the issue and the limited possibilities of its detailed presentation in the form of an article, only some of the selected items of literature were referenced in work, although the list of references is extensive. A particular limitation in the analysis of literature is posed by the problem of attributing the author to the discipline of geography (differences in the scope of scientific degrees obtained and self-determination of research interests). However, it was assumed that the most crucial issue is the scientific problem (the subject of interest in the problems of geography of industry) rather than the formal attribution of a given author to the discipline of geography in the light of Polish division of sciences.

\section{DEVELOPMENT OF PROBLEMS AND RESEARCH DIRECTIONS OF GEOGRAPHY OF INDUSTRY DURING THE CENTRALLY CONTROLLED ECONOMY}

As a result of intense industrialisation in the 19th century and the first decades of the 20th century, geography of industry emerged as an independent sub-discipline of geography with strictly defined goals and research tasks, as well as specific research methods. It is assumed that it was distinguished in the structure of world economic geography in the 1930s and 1940s. In Poland, geography of industry was formally distinguished in the structure of economic geography, along with geography of transport, geography of agriculture and geography of settlement, at a methodological conference in Osieczna near Poznań (now Wielkopolskie Voivodeship), held from 28 November to 1 December 1955 (Misztal, Zioło, 1998a). As commented by J. Grzeszczak (2011), this conference decided the fate of the Polish economic geography for the next few decades. In his opinion, it can be said without exaggeration that the roots of contemporary economic geography are still stuck in the ground prepared by this conference, and this applies above all to the branch specialisation developed on a large scale. It involved a complete reconstruction of relevant research plans, curricula and organisational structures (Grzeszczak, 2011). As stated by T. Stryjakiewicz (2010), the boundaries between a significant part of industrial and service activities have been blurring recently, therefore the problems of geography of industry "blends in" with the research in the 
field of economic geography (taken as a whole, i.e. without the "branch" division into sub-disciplines) and this trend is consistent with the global trend. It is associated with difficulties in the analysis of contemporary changes in geography of industry which is related to the emerging problems in defining the scope of the subject discipline during the period of industry servicing.

Of particular importance to the academic achievements of geography of industry in Poland are bibliographies of the distribution of industry, including literature from 1945-1962 (Fajferek, 1963) and bibliography of the geography of industry for 1963-1983 (Pakuła, Troc, 1987). Moreover, the achievements of geography of industry include bibliographies on regional planning in 1945-1965 (Zawadzki, 1969) and in 1966-1970 and 1971-1980 (Wrzosek, Zawadzki, 1974, 1985), as well as a discussion of research of the former Committee for Research on the Regions under Industrialisation of the Polish Academy of Sciences (Czyżewska, 1969).

The fundamental role in organising the research issues of geography of industry includes papers on determining the directions of research on the spatial structure of industry and the prospects for its development (Leszczycki, Kukliński, 1964; Kukliński, 1964, 1976, 1981), basic research directions (Grzeszczak, 1964, 1985, 1991), determining trends in the development of geography of industry (Dobrowolska, 1965, 1978; Straszewicz, 1987), new tendencies and directions in spatial research of industry (Kortus, 1978a, 1978b, 1987, 1999; Kuciński, 1998) and presenting an outline of the research concept of spatial forms of industry concentration and spatial structure of industry (Zioło, 1971, 1976, 1978, 1987, 1997, 2008; Pakuła, 1978, 1983).

In the years of the central control system of the economy, covering the phase of industrial development, an unusually large interest in the problems of geography of industry resulted from the fact that industry was treated as a leading factor of the socio-economic development. A unique role in this area was played by studies devoted to the impact of industry on socio-economic and cultural development, especially regional systems. They intensified as part of the work of the former Committee for Research on the Regions under Industrialisation, which was related to the analysis of the impact of developing substantial industrial investments on the transformation of agricultural areas. Particularly comprehensively, these studies were conducted in the "academic school" of prof. Maria Dobrowolska (Dobrowolska, 1965; Zioło, 1978, 2017).

Stryjakiewicz (1987, see also 1992, 2010, 2014), analysing the research directions of geography of industry in 1945-1980, distinguishes a number of primary groups of problems that concern: the origins and development of centres, districts and industrial regions, branch and spatial structure of industry, industrialisation processes, industry links with the natural environment, location factors and assessment of the efficiency of industry operations, as well as theoretical and methodological issues. Kortus (1987) after Kukliński (1981) discussed current trends and research problems in geography of industry and then presented selected elements of the functioning of the global industrial system and desirable research approaches.

S. Misztal (1997), and S. Misztal and Z. Zioło (1998a), after A. Kukliński (1976) and B. Kortus (1986), as the primary research directions of geography of industry developed in the post-war years enumerate landscape, physiographic, historical-geographical, technological-economic, behavioural and systemic directions. S. Misztal (1997) also distinguished the methodological-theoretical and planning direction, related to the studies on creating plans for economic development based on industrialisation. 
Attention was also paid to disharmony between the intensification of the industrialisation and urbanisation processes (Fajferek, Zioło, 1979, 1983).

The primary goal of the landscape direction in geography of industry was to study the industrial landscape, referred to as a fragment of the surface of the Earth, where industrial plants that meet specific economic and social functions visually dominate. This trend in Poland in the post-war period did not find many supporters, although recently there has been a return to research on cultural landscapes; industrial landscapes are also distinguished in the latest delimitation of landscapes (Chmielewski, Myga-Piątek, Solon, 2015). These studies, among others, refer to earlier studies of M. Dobrowolska in this regard (1948). In the physiographic direction, attention was mainly paid to the influence of mutual relations between an industrial enterprise and individual elements of the natural environment. On the one hand, they explained their role as essential factors in the location of industry, and on the other, the influence of industrial activity on changes in the elements of the natural environment was determined. Currently, due to the increasing degradation of individual elements of the natural space, this direction is reflected in ecological research, focusing on the impact of industry on nature and the environment of human life.

The primary goal of the historical-geographical direction was to explain the development processes of industrial plants, as well as the structure of the industry in various spatial systems based on historical research. Using the historical method, it was attempted to determine the location factors and conditions affecting the development of industrial plants representing various industries or their stagnation, recession or disappearance. The beginnings of the development of the factory industry, often developed on the activities of factories and crafts, were sought after. At the same time, the process of transformation of industrial structures was analysed concerning the current administrative division and according to the current industry classification. Using the genetic method the current industry structure of the studied area was often sought. Attention was paid to the stability of industrial plants in the modern industrial structure, change of their potential and durability of the functions performed. In the technical and economic direction, however, the primary attention was paid to the study of changes taking place in the technology of industrial production, which influenced the increase of production potential and changes in the plant location. Attention was paid to the variability of location factors and the degree of attractiveness of the area for developing production activities under the influence of scientific and technological progress. In behavioural studies, it was assumed that in order to explain the contemporary industrial structure and potential, it is necessary to analyse behavioural changes of individual investors or other decision makers who used specific conditions, mainly legal, financial and market conditions, thus exerting roper influence on the selection of plant locations and directions of development of industrial enterprises.

The systemic direction developed as a result of the use of the concept of dynamic systems and statistical methods in the field of geography of industry. It was assumed that the industrial system includes specific elements and relations between them. On this basis, attempts were made to explain the functioning of industrial enterprises, as well as the intensification of active and passive relations taking place between enterprises in the structures of industrial centres and districts, as well as their connection with the surrounding. It was assumed in this respect that both enterprises and forms of industry concentration (centres, industrial districts) are not isolated units, but function 
as elements of a more complex spatial structure of industry and the structure of geographical space. Based on the outlined research concepts, attempts were made to build theoretical models of the functioning and development of an industrial enterprise, shaping territorial forms of industry concentration (centre, district, complex), changes in the spatial structure of industry and determining its place in geographical space (Zioło, 1971, 1976, 1978, 1987, 1997). These directions have been represented in the studies of members of the Industrial Geography Commission of the Polish Geographical Society from the very beginning of its establishment in 1979 (Zioło, Rachwał, Kilar, 2018). It is due to the activities of the majority of geographers of industry in this Commission, which is also taking place today.

The significant achievements of Polish geography of industry were presented in the joint study of the Industrial Geography Commission of the Polish Geographical Society in the years 1976-1996 (Misztal, Zioło, 1998b). Individual authors presented research results of national geographic centres (Warsaw, Krakow, Łódź, Poznań, Katowice, Wrocław, Toruń, Gdańsk, Lublin, Kielce, Słupsk, and Rzeszów), documenting it with extensive literature on the subject. Generally, the editors of the volume distinguished five research directions from the point of view of the applied methods and based on the studies listed above: information-statistical, analytical-explanatory, planning-forecasting, cartographic, raw material (Zioło, Rachwał, Kilar, 2018). In the analytical and synthesising studies, the methods of these research directions often merge with each other, which undoubtedly increases the methodological and application value of their results. In individual centres in the undertaken studies, researchers pay attention to directions of products sales, supply of industry with energy, water and other raw materials and components, sewage disposal and waste management, cooperative links, economic effects of location and industry development, social, economic and ecological effects of processes of industrialisation in regional systems, delimitation of industrial centres and districts, processes of industrial deglomeration, restructuring and privatisation of industry, as well as problems of teaching geography of industry in school and university education.

\section{RESEARCH TOPICS OF STRUCTURAL CHANGES IN INDUSTRY IN THE YEARS OF ECONOMIC TRANSFORMATION}

A smaller interest in the issues of geography of industry is noted after 1989, in the years of transformation and implementation of market economy rules. Especially in the early years of the reconstruction of management system of the national economy, the processes of political and economic transformation were accompanied by the collapse of many critical industrial enterprises, which contributed to the decreasing importance of industry in the structure of national economy (incl. Rutkowska-Gurak, 2000; Kieżun, 2012; Karpiński, Paradysz, Soroka, Żółkowski, 2013; Ślązak, 2016). Rachwał $(2001,2006)$ drew attention to erroneous decisions regarding the directions of state intervention in the framework of industrial policy, which was manifested in supporting traditional branches and industry plants whose role in the economy is declining, leaving without such support the plants representing modern industry branches, such as electronic industry (Rachwał, 2001). Attempts to repair these errors through reindustrialisation programs are now costly. Some researchers have mistakenly accepted the liquidation of enterprises and the shrinking role of industry as a labour market as 
a sign of the country entering the phase of post-industrial development or cumbersome deindustrialisation processes. This was accompanied by increasing difficulties in access to the empirical database regarding the operation of industrial enterprises and limited information about official statistics. Accepting the thesis about the decreasing role of industry as the base of economic development in favour of service activities, influenced changes in research interests of many people and undertaking issues for which broader and easier access to information was possible (Zioło, Rachwał, 2008, 2014). It should be emphasised, however, that the researchers (Kilar, Rachwał, Wiedermann, 2008; Rachwał, 2008, 2009, 2011a, 2011b; Rachwał, Kilar, Wiedermann, 2009; Kilar, Rachwał, 2014) pointed out that these processes are not so much a manifestation of deindustrialisation and the decreasing importance of industry in the economy; instead they testify to the decline in the role of industry in the field of labour resource activation as a result of mechanisation, automation, robotics and computer control of production processes. The problem of limiting access to data on industrial development in new management conditions and thus the decrease in the interest of researchers in these problems attracted the attention, among others, of T. Rachwał (2008), and on the issue of the return of geographers of industry in research into economic sciences or social sciences, or other geographic sub-disciplines - P. Czapliński $(2008,2009)$. On the other hand, it should be noted that profound economic changes, including industry sector, have naturally caused researchers' interest in these changes. Therefore, despite the difficulties in accessing data, many economic geographers have taken up research on the transformation of industrial structures, seeing this as an opportunity to explain changes in transition from a centrally managed economy to market economy in Poland and many other countries of Central and Eastern Europe, so far unprecedented in this scale in economic history.

The issue of the impact of changes in the management system and the implementation of market rules on the industry activity was reflected in research studies focused around the Industrial Geography Commission of the Polish Geographical Society. After the establishment of the Commission in 1979, the issues concerned were mainly related to the location and shaping of an industrial plant and spatial forms of industry concentration (centre, district), regional problems of industrialisation, followed by the behaviour of industry in the changing economic and political system. In 1995, a summary of the research problems of geography of industry was presented in the aforementioned collective work "The achievements of Polish geography of industry in the research of academic centres" (Misztal, Zioło, 1998b). Later, P. Czapliński (2008, 2009), T. Stryjakiewicz (2010, 2014), and Z. Zioło (2014) determined research directions, as well as the strengths and weaknesses of Polish geography of industry, including those related to other industrial sciences.

In the years of implementing the market economy, the importance of the services sector in the activation of labour resources and the dynamics of socio-economic changes in spatial systems is growing, and the boundaries between industrial and service activities are disappearing, of which the IT sector is a good example. It was reflected in the studies of the Industrial Geography Commission of the Polish Geographical Society, in which, apart from the research topics of the industry, selected entities and sectors of service activity are also presented. Attempts are also made to evaluate innovativeness and structural changes in both sectors of the economy (Dominiak, Rachwał, 2016). In the area of industrial issues, the primary attention was paid to the following: 
- adaptation of industry to new conditions of management and transformation of spatial and industry structures of industry in the process of implementing market economy rules (e.g. Rydz, Jażewicz, 1994; Matykowski, Tobolska, 1994; Tobolska, 1997; Stryjakiewicz, 1999; Gierańczyk, 2000; Domański, Guzik, Gwosdz, 2005; Gwosdz, Micek, 2010; Czapliński, 2010, 2014; Rachwał, 2011a, 2012, 2015b; Gierańczyk, Rachwał, 2012; Mrozińska, 2013);

- international and internal (national) determinants of the development of domestic industry and its structural changes under the influence of globalisation processes, moving to the informational phase of civilisation development and - what is essential in Polish conditions - the process of European integration and implementation of new legal instruments related to systemic transformation (see e.g. Zioło, Rachwał, 2006, 2016a);

- the impact of various international and national conditions on the functioning of industrial enterprises as the essential elements of the spatial structure of industry (see, e.g., Rachwał, Zioło, 2016b; Zioło, 2016);

- effects of the restructuring of enterprises and spatial and branch structures on the background of the changing business environment (e.g. Pukowska-Mitka, Tkocz, 1992; Rachwał, 2002, 2006, 2010, 2011b);

- the role of foreign capital in increasing innovation and changes in spatial, ownership and branch structures of Polish industry (e.g. Domański, 1999, 2002, 2003a; Stryjakiewicz, 2005c; Brezdeń, 2006; Tkocz, Sobala, 2006);

- the impact of the economic crisis on the behaviour of industrial enterprises and changes in national and regional economic structures (e.g. Czapliński, 2011; Zioło, Rachwał, 2011; Rachwał, 2011c, 2014; Domański, Guzik, Gwosdz, Dej, 2013; Kilar, 2014a; Zioło, 2014b);

- the impact of industry innovation on the transformation of the economy in spatial systems (e.g. Bal-Woźniak, 2009; Borowiec, Dorocki, Jenner, 2009; Rachwał, 2012; Zioło, 2012; Brezdeń, 2015; Gierańczyk, Sadoch, 2015; Rachwał, Wiedermann, 2015);

- shaping spatial industrial systems, functioning of industrial centres and districts, as well as industrial clusters treated as new forms of industry concentration (e.g. Dziadek, 1990; Szajnowska-Wysocka, 1990; Rochnowski, 1993; Rydz, Jażewicz, 1997; Gierańczyk, Stańczyk, 2001; Domański, 2003b; Pakuła, 2003; Zioło, 2008b; Dyba, Stryjakiewicz, 2014; Tkocz, 2015; Domański, 2015; Dyba, 2017);

- the role of industry in the development of a knowledge-based economy (e.g. Domański, 2000; Rachwał, Wiederman, Kilar, 2009; Heder, Tkocz, 2013; Rachwał, 2013; Zioło, Rachwał, 2013);

- changes in the export structure of Polish industry (e.g. Komornicki, 2006; Wieloński, 2010; Szejgiec, Komornicki, 2015).

The interest of researchers in the field of factors and the assessment of the location of the industry was continual (though slightly smaller than in previous years) (Fierla, 1994, 1996; Fierla, Kuciński, 1996, Kuciński, 2001; Stryjakiewicz, 2009; Tobolska, 2011; Godlewska-Majkowska, 2013, 2015, 2016). In addition, research issues not addressed directly to the structural changes of Polish industry regarding control functions of international corporations and large industrial enterprises and their role in the development of spatial arrangements were also undertaken (Domański, 2005; Zioło, 2006; Śleszyński, 2007, 2008, 2014, 2015; Kilar, 2014b; Raźniak, Dorocki, 
Winiarczyk-Raźniak, Płaziak, Szymańska, 2016; Raźniak, Dorocki, Winiarczyk-Raźniak, 2018; Boguś, Dorocki, 2018), as well as processes of transformation of the industry or its selected departments in selected countries (e.g. Dorocki, Borowiec, Boguś, 2013; Dorocki, 2014; Wójtowicz, Rachwał, 2017; Wójtowicz, 2017).

Empirical research studies were undertaken at various spatial scales. The following levels of analysis can be distinguished here:

- mega- (structure of global industry),

- macro- (structure of domestic industry),

- mezo- (branch structure of the industry and regional structure of the industry),

- microeconomic (an industrial enterprise, including internal changes of enterprise structures, e.g. employment structure, production mix).

None of these levels of analysis is dominant, but in the last thirty years there has been a systematic decline in interest in the research of individual industrial enterprises, in particular their spatial relationships in terms of sales and supply, technical and economic aspects of functioning, and links to the labour market, due to the difficult access to individual data or business secret, which often prevents the publication of studies using such data (Domański, 1997; Rachwał, 2008). It is worth emphasising, after B. Domański (1997), that geography of enterprises is an essential trend, though undervalued, in the study of geography of industry. It is because an industrial enterprise is a fundamental element of the industrial structure, and many transformations on a regional, branch or national scale cannot be well interpreted without considering the functioning of enterprises. Therefore, many geographers of industry, despite the difficulties, try to undertake them. They mainly concern the ownership structure, production, employment, sources of supply, sales directions, technological issues and environmental impact (in the scope of pollutant emissions, sewage disposal, waste collection), as well as revenues and costs of enterprises. As some of the industrial enterprises in the transformation years were closed down, the problems of transformations and revitalisation of industrial areas were also taken up (e.g. Domański, 2002a).

In the field of empirical studies, an apparent evolution of research interests is observed, referring to the stages of economic transformation and changes in the international surroundings; while maintaining interest in issues that have been the subject of research into geography of industry for many years. In this respect, the following five research periods can be distinguished:

- initial period of economic transformation (period of the so-called transformational shock): 1989-1993, in which research focused on the impact of a sudden change in the management system on industrial activity, with particular emphasis on changes in ownership structures,

- fundamental transformation period: 1994-2004, in which, among others, studies related to adaptation of enterprises and individual industries to new management conditions, the progressing privatisation process and the role of foreign capital in this area; studies were also undertaken in relation to the impact of the exclusive economic zones mechanism on the spatial structure industry,

- the primary phase of European integration: 2004-2007, in which researchers paid particular attention to the effects of Poland's entry into the single European market for domestic industry, 
- period of the global economic crisis: 2008-2015, in which the studies related to the impact of crisis phenomena in the country and the international surroundings on the functioning of enterprises and the transformation of industrial structures,

- period of recovery from the crisis (since 2016), in which researchers pay attention to new challenges and barriers to industrial development.

Various methods and research approaches were adopted in the studies. T. Stryjakiewicz (2010) distinguished three contemporary methodological orientations: evolutionary, relational, and institutional. Relatively rarely, studies were based only on one of these three contemporary orientations, but there is much interest in institutional orientation (e.g. Stryjakiewicz, 2007; Stachowiak, Stryjakiewicz, 2008; Stachowiak, 2008, 2009; Micek, Gleadle, Dawidko, 2014).

Theoretical problems focused mainly on attempts to model approaches and building theoretical concepts of geography of industry against civilisation development, building a knowledge-based economy and internationalisation of production activities. Particular attention was paid to: attempts to improve the spatial structure of industry, modelling the functioning of geographical space and determining the place of industrial enterprise and territorial forms of industry concentration, industrial transformation in changing economic conditions and its functions in regional, national and global economy (Zioło, 1997, 2008a, 2017; Gierańczyk, 2008a), improving the research problems of enterprises (Rachwał, 2008), attempts to define changes in industry location trends in the era of globalisation (Gierańczyk, 2008b), the concept of multiplier effects in determining the impact of industry on the environment (Rachwał, Wiedermann, 2008; Domański, Gwosdz, 2010), shaping the network economy (Stryjakiewicz, 2001, 2005a, 2005b; Paszkowski, 2008). Assessment of research problems, as well as strengths and weaknesses of Polish geography of industry (Kuciński, 1992; Parysek, 1993; Pączka, 1994; Stryjakiewicz, 2014) and evaluation of research problems and achievements in geography of industry against the economic sciences (Czapliński, 2008) were also carried out. Problems of structural changes indicated as one of the trends of research, whereby the importance of research in the field of geography of industry in the field of changes in the spatial structure of industry is stressed. It was assumed that research should be developed in order to comprehend the changing structures of industry and services in specific social, economic and spatial conditions.

It is worth emphasising that the studies undertaken in the theoretical-methodological trend often included a partial exemplification of the presented models and theories based on empirical research.

The results of the research were published mainly in the form of articles in national (mainly the Studies of the Industrial Geography Commission of the Polish Geographical Society as the only journal in Poland devoted to the geography of industry) or foreign journals. The prestige of the journal or publisher and the so-called scoring, or the value of a given journal on ranking lists of journals of the Polish Ministry of Science and Higher Education is crucial. For this reason, publications on geography of industry in the form of scientific monographs are rare. Low so-called "score value" of chapters in such monographs as well as entire monographs caused little interest in this type of presentation of results. The only exceptions were monographic publications related to obtaining scientific degrees - doctorates, habilitation or professorship. The same factor causes little interest in the development of academic textbooks for geography of industry in recent years, except for the exercise book on economic geography with an 
industry chapter (Czapliński, Rachwał, Tobolska, Uliszak, 2013). The phenomenon of using only the score value while choosing the place of publication should be considered harmful because it means the influence of non-subject factors on the selection of the best form of dissemination of research results. Part of the studies was carried out on behalf of various institutions and enterprises, e.g. local self-government, ministries, bodies managing special economic zones or industrial parks, which is why their results were published as research reports or expert reports. Some of the results were presented in the form of conference abstracts, a report from the Polish Academy of Sciences committee meetings and posters at conferences. Due to the lack of the habit of publishing posters, this is the most elusive form of presentation, if the authors do not decide to prepare a scientific article on this subject.

\section{CONCLUSIONS AND RECOMMENDATIONS}

Polish geography of industry has undertaken significant scientific and economic research problems of structural changes in industry in the period of economic transformation, continually updating its research priorities. Researchers quickly reacted to changes in the legal and political conditions of the functioning of national economy, despite numerous organisational barriers related to limited access to data and not very favourable location of economic geography in the structure of sciences, often attributed to natural sciences with entire geography. Undoubtedly, however, the advantage of empirical and descriptive studies of selected examples over syntheses is noticeable.

In the process of developing research issues in the field of geography of industry and methodology of studies undertaken in Poland, many patterns were used from foreign literature, but also many new proposals were put forward that could be used by foreign researchers. A particular contribution of Polish geography of industry is noted in the field of structural changes in industry during the period of economic transformation. It seems, however, that until now too little attention has been paid to the promotion of national research results in international environment, which affects the relatively low knowledge of Polish achievements by geographers, economists and representatives of other disciplines dealing with the transformation of industry. It seems that in this respect, these achievements have been relatively rarely published in the most renowned international journals.

The prospects of further development of research in the field of geography of industry in Poland may be affected by barriers of human nature. Geographers' departure from this issue can be observed. The basis of this process is very diverse. On the one hand, it is related to limitations in access to detailed data, and on the other hand, to the above-mentioned blurring of the boundaries between the industrial and services sectors, which raises questions about the validity of a further "industry" approach to research in the field of economic geography. It seems, however, that when production activity is still of great importance in the functioning of national economies at all stages of development, even the most developed, and reindustrialisation programs are implemented in many countries, research in geography of industry still has a future and essential cognitive and application functions to meet.

It seems that in the coming years particular attention should be paid to the studies synthesising existing research in the field of transformation of industrial structures in the period of change in the economic system in order to develop model approaches and 
determine the best research methods of this process. The following research issues also seem to be worth undertaking:

- directions of expansion of Polish industrial enterprises on international markets, including mergers and acquisitions of foreign enterprises due to high competitiveness in the international environment of many domestic enterprises and their more and more advanced functions on global markets,

- various network connections of domestic industry with global industry,

- still existing barriers to the development of industry, related to the relatively low innovation of Polish economy, low technological advancement of some industries and the lack of adequate human resources on the labour market,

- directions of new industrial policy and evaluation of the implementation of re-industrialisation programs, based on the concept of industry 4.0, in Poland against the experience of other countries, including the industrial policy of the European Union,

- improvement of goals and methods, as well as the implementation of educational content in the field of industry in school and academic geography, especially in the conditions of implementing the reform of the education system in Poland.

\section{References}

Bal-Woźniak, T. (2009). Infrastruktura systemu innowacyjnego jako czynnik transformacji struktur przemysłowych [Infrastructure of innovative system as a factor of transformation of industrial structures]. Prace Komisji Geografii Przemysłu Polskiego Towarzystwa Geograficznego [Studies of the Industrial Geography Commission of the Polish Geographical Society], 12, 45-57.

Boguś, M., Dorocki, S. (2018). Międzynarodowe korporacje biotechnologiczne i farmaceutyczne na świecie [International Biotechnological and Pharmaceutical Corporations in the World]. Prace Komisji Geografii Przemysłu Polskiego Towarzystwa Geograficznego [Studies of the Industrial Geography Commission of the Polish Geographical Society], 32(2), 129-141.

Borowiec, M., Dorocki, S., Jenner, B. (2009). Wpływ zasobów kapitału ludzkiego na kształtowanie społeczeństwa informacyjnego i innowacyjności struktur przemysłowych [Influence of human capital supplies on the creation of information society and the innovation of industrial structures]. Prace Komisji Geografii Przemysłu Polskiego Towarzystwa Geograficznego [Studies of the Industrial Geography Commission of the Polish Geographical Society], 13, 95-109.

Brezdeń, P. (2006). Uwarunkowania bezpośrednie inwestycji zagranicznych i ich wpływ na umiędzynarodowienie działalności produkcyjnej w województwie dolnośląskim [Direct factors of foreign investments and their impact on the internationalisation of production activities in Dolnośląskie Voivodeship]. Prace Komisji Geografii Przemysłu Polskiego Towarzystwa Geograficznego [Studies of the Industrial Geography Commission of the Polish Geographical Society], 8, 60-73.

Brezdeń, P. (2015). Wybrane aspekty przemian strukturalnych i innowacyjności przemysłu Śląska - ujęcie przestrzenne [Selected Aspects of the Structural Changes and the Innovativeness of Silesian Industry - a Spatial Perspective]. Prace Komisji Geografii Przemysłu Polskiego Towarzystwa Geograficznego [Studies of the Industrial Geography Commission of the Polish Geographical Society], 29(2), 123-146.

Chmielewski, T.J., Myga-Piątek, U., Solon, J. (2015). Typologia aktualnych krajobrazów Polski. [Typology of Poland's current landscapes]. Przegląd Geograficzny, 87(3), 377-408.

Czapliński, P. (2008). Problematyka badawcza przemysłu w geografii na tle nauk ekonomicznych. [The problems of industry research in geographic and economic sciences]. Prace Komisji Geografii Przemysłu Polskiego Towarzystwa Geograficznego [Studies of the Industrial Geography Commission of the Polish Geographical Society], 11, 46-52. 
Czapliński, P. (2009). Wybrane problemy badawcze w geografii Przemysłu [Selected research problems in the geography of industry]. In: W. Maik, K. Rembowska, A. Suliborski (ed.). Ujęcia i problemy badawcze we współczesnej geografii [Approaches and research problems in contemporary geography]. Bydgoszcz: Instytut Geografii i Gospodarki Przestrzennej WSG w Bydgoszczy, 115-123.

Czapliński, P. (2010). Przestrzenny wymiar procesów transformacji przemysłu w województwie pomorskim [Spatial industrial transformation processes in the Pomorskie voivodship]. Prace Komisji Geografii Przemysłu Polskiego Towarzystwa Geograficznego [Studies of the Industrial Geography Commission of the Polish Geographical Society], 15, 130-141.

Czapliński, P. (2011). Funkcjonowanie przemysłu przetwórstwa rybnego w Polsce w okresie kryzysu gospodarczego [Functioning of the fish processing industry in the period of economic crisis]. Prace Komisji Geografii Przemysłu Polskiego Towarzystwa Geograficznego [Studies of the Industrial Geography Commission of the Polish Geographical Society], 17, 114-128.

Czapliński, P. (2014). Processes of Transformation of Spatial Structure of Fish Processing Industry in Poland. Prace Komisji Geografii Przemysłu Polskiego Towarzystwa Geograficznego [Studies of the Industrial Geography Commission of the Polish Geographical Society], 25, 151-162.

Czapliński, P., Rachwał, T., Tobolska, A., Uliszak, R. (2013). Geografia gospodarcza. Przewodnik do ćwiczeń [Economic geography. Exercise guide]. Poznań: Bogucki Wydawnictwo Naukowe

Czyżewska, B.(ed.). (1969). Bibliografia polskich prac badawczych za lata 1962-1965 [Bibliography of Polish research works for the years 1962-1965]. Zeszyty Badań Rejonów Uprzemysławianych, 35.

Dobrowolska, M. (1948). Dynamika krajobrazu kulturowego [Dynamics of cultural landscape]. Przegląd Geograficzny, 21(3-4), 151-205.

Dobrowolska, M. (1965). Tendencje rozwojowe geografii przemysłu w okresie XX-lecia Polski Ludowej [Trends in the development of the geography of industry during the twenty years of People's Republic of Poland]. Przegląd Geograficzny, 37(4).

Dobrowolska, M. (1978). Procesy industrializacji i urbanizacji jako czynniki wzrostu i przemian struktury przestrzennej rejonu uprzemysławianego [Industrialisation and urbanisation processes as factors of growth and transformation of the spatial structure of the region under industrialisation]. In: Przemiany społeczno-ekonomiczne Tarnobrzeskiego Rejonu Uprzemysławianego [Social and economic transformations of the Tarnobrzeg Region under Industrialisation]. Warszawa: Polska Akademia Nauk, Komitet Badań Rejonów Uprzemysławianych, Wydawnictwo Naukowe PWN, 11-24.

Domański, B. (1997). Geografia przedsiębiorstw - niedoceniany nurt badań w polskiej geografii ekonomicznej [Geography of enterprises - an undervalued research trend in the Polish economic geography]. In: B. Domański (ed.). Geografia, Człowiek, Gospodarka [Geography, Man, Economy]. Kraków: Wydawnictwo Instytutu Geografii Uniwersytetu Jagiellońskiego, 101-112.

Domański, B. (2000). Some aspects of the development of Polish manufacturing in the perspective of knowledge-based economy. In: A. Kukliński (ed.). The knowledge-based economy. The European challenges of the 21st century. Warsaw: State Committee for Scientific Research, 281-287.

Domański, B. (2001). Kapitał zagraniczny w przemyśle Polski. Prawidłowości rozmieszczenia, uwarunkowania i skutki [Foreign capital in the Polish industry. Distribution patterns, conditions and effects]. Kraków: Instytut Geografii i Gospodarki Przestrzennej Uniwersytetu Jagiellońskiego.

Domański, B. (2002a). Przekształcenia terenów poprzemysłowych w województwach śląskim i małopolskim - prawidłowości i uwarunkowania [Transformations of post-industrial areas in Śląskie and Małopolskie Voivodeships - regularities and conditions]. Prace Komisji Geografii Przemysłu Polskiego Towarzystwa Geograficznego [Studies of the Industrial Geography Commission of the Polish Geographical Society], 3, 51-59.

Domański, B. (2002b). Zagraniczne inwestycje przemysłowe a obszary metropolitalne w Polsce [Foreign industrial investments and metropolitan areas in Poland]. Prace Komisji Geografii Przemystu Polskiego Towarzystwa Geograficznego [Studies of the Industrial Geography Commission of the Polish Geographical Society], 4, 9-18. 
Domański, B. (2003a). Economic trajectory, path dependency and strategic intervention in an old industrial region: the case of Upper Silesia. In: R. Domański (ed.). Recent advances in urban and regional studies. Warsaw: Polish Academy of Sciences, Committee for Space Economy and Regional Planning, 133-153.

Domański, B. (2003b). Industrial change and foreign direct investment in the postsocialist economy: the case of Poland. European Urban and Regional Studies, 10(2), 99-118.

Domański, B. (2005). Transnational corporations and the postsocialist economy: learning the ropes and forging new relationships in contemporary Poland. In: C. Alvstam, E. Schamp (ed.). Linking Industries across the World: Processes of Global Networking. Aldershot: Ashgate, 147-172.

Domański, B. (2015). Współczesne procesy przemian regionalnych przemysłu Polski - próba interpretacji [Contemporary processes of regional industrial changes in Poland - possible interpretations]. Prace Komisji Geografii Przemysłu Polskiego Towarzystwa Geograficznego [Studies of the Industrial Geography Commission of the Polish Geographical Society], 29(4), 40-53.

Domański, B., Guzik, R., Gwosdz, K. (2005). The new spatial organization of automotive industry in Poland in the context of its changing role in Europe. Studia Regionalia, 15, 153-171.

Domański, B., Gwosdz, K. (2010). Multiplier effects in local and regional development. Quaestiones Geographicae, 29(2), 27-38.

Domański, B., Guzik, R., Gwosdz, K., Dej, M. (2013). The crisis and beyond: the dynamics and restructuring of automotive industry in Poland. International Journal of Automotive Technology and Management, 13(2), 151-165.

Dominiak, J., Rachwał, T. (2016). Chief development tendencies, structural changes and innovativeness of the industrial and service sectors in Poland. Quaestiones Geographicae. 35(4), 49-69.

Dorocki, S. (2014). Contemporary Trends in the Development of the Pharmaceutical Industry in the World. Prace Komisji Geografii Przemysłu Polskiego Towarzystwa Geograficznego [Studies of the Industrial Geography Commission of the Polish Geographical Society], 25, 108-131.

Dorocki, S., Borowiec, M., Boguś, M. (2013). Przestrzenne zróżnicowanie rozwoju przemysłu biotechnologicznego [Spatial Diversity of the Biotechnological Industry's Development]. Prace Komisji Geografii Przemysłu Polskiego Towarzystwa Geograficznego [Studies of the Industrial Geography Commission of the Polish Geographical Society], 21, 94-120.

Dyba, W. (2017). Klastry meblarskie na tle struktury przestrzennej przemysłu meblarskiego w Polsce [Furniture Clusters in the Spatial Structure of the Furniture Industry in Poland]. Prace Komisji Geografii Przemysłu Polskiego Towarzystwa Geograficznego [Studies of the Industrial Geography Commission of the Polish Geographical Society], 31(1), 38-51.

Dyba, W., Stryjakiewicz, T. (2014). Inicjatywy klastrowe jako szansa rozwoju przemysłu meblarskiego w Polsce w warunkach kryzysu - przykład Swarzędzkiego Klastra Producentów Mebli [Cluster initiatives as a chance for the development of the furniture industry in Poland in the conditions of a crisis: The example of the Swarzędz Cluster of Furniture Producers]. Prace Komisji Geografii Przemysłu Polskiego Towarzystwa Geograficznego [Studies of the Industrial Geography Commission of the Polish Geographical Society], 27, 181-196.

Dziadek, S. (1990). Kształtowanie się i dynamika rozwoju ośrodków przemysłowych Rybnickiego Okręgu Węglowego [Formation and dynamics of development of industrial centers of the Rybnik Coal Area]. In: Z. Zioło (ed.). Problematyka ośrodka przemysłowego w akademickim kształceniu nauczycieli geografii [Problems of the industrial center in the academic education of geography teachers]. Kraków: Centralny Ośrodek Metodyczny Studiów Nauczycielskich, Wyższa Szkoła Pedagogiczna w Krakowie, 50-64

Fajferek, A. (1963). Przemysł [Industry]. Biuletyn Komitetu Przestrzennego Zagospodarowania Kraju Polskiej Akademii Nauk, 9(28).

Fajferek, A., Zioło, Z. (1979). Próba określenia stopnia wyprzedzenia procesów urbanizacji przez procesy industrializacji [Attempt to determine the degree of advancement of industrialisation processes over urbanisation processes]. Zeszyty Badań Rejonów Uprzemysławianych, 71.

Fajferek, A., Zioło, Z. (1983). Opóźnienie procesów urbanizacji w stosunku do procesów industrializacji w woj. Tarnobrzeskim [Delay of urbanisation processes in relation to processes of industrialisation in Tarnobrzeg Voivodeship]. Zeszyty Badań Rejonów Uprzemysławianych, 77. 
Fierla, I. (ed.) (1994). Zmiany uwarunkowań lokalizacji przemysłu w Polsce. Część I. Monografie i Opracowania [Changes of conditions for the location of the industry in Poland. Part I. Monographs and Studies]. Warszawa: Oficyna Wydawnicza Szkoły Głównej Handlowej.

Fierla, I. (ed.) (1996). Zmiany uwarunkowań lokalizacji przemysłu w Polsce. Część II. Monografie i Opracowania [Changes of conditions for the location of the industry in Poland. Part II. Monographs and Studies].Warszawa: Oficyna Wydawnicza Szkoły Głównej Handlowej.

Fierla, I., Kuciński, K. (1996). Współczesna ewolucja czynników lokalizacji przemysłu w Polsce [Contemporary Evolution of Localisation Factors of Industry in Poland]. Monografie i Opracowania Szkoły Głównej Handlowej, 408, 7-74.

Gierańczyk, W. (2008b). Badania struktur przemysłowych w Polsce w dobie globalizacji ze szczególnym uwzględnieniem struktury przestrzennej [Research into Polish industrial structures in the globalization era: the industrial spatial structure]. Prace Komisji Geografii Przemysłu Polskiego Towarzystwa Geograficznego [Studies of the Industrial Geography Commission of the Polish Geographical Society], 11, 26-39.

Gierańczyk, W. (2000). Wpływ transformacji ustrojowej na zmiany strukturalne w przemyśle województwa toruńskiego [Impact of political transformation on structural changes in the industry of Toruń Voivodeship]. Prace Komisji Geografii Przemysłu Polskiego Towarzystwa Geograficznego [Studies of the Industrial Geography Commission of the Polish Geographical Society], 1, 77-88.

Gierańczyk, W. (2008a). Problematyka definiowania zmian w tendencjach lokalizacji przedsiębiorstw przemysłowych w dobie globalizacji [Problems in defining changes in enterprise-location tendencies in the globalization era]. Prace Komisji Geografii Przemysłu Polskiego Towarzystwa Geograficznego [Studies of the Industrial Geography Commission of the Polish Geographical Society], 11, 86-97.

Gierańczyk, W., Rachwał, T. (2012). Structural changes in the industry of Poland against the background of eastern European Union states. Quaestiones Geographicae, 31(2), 83-93.

Gierańczyk, W., Sadoch, A. (2015). Współdziałanie aktywnych innowacyjnie przedsiębiorstw przemysłowych w Polsce według województw w latach 2010-2012 [Cooperation of innovate industrial enterprises in Poland by voivodeships (2010-2012)]. Prace Komisji Geografii Przemystu Polskiego Towarzystwa Geograficznego [Studies of the Industrial Geography Commission of the Polish Geographical Society], 29(4), 68-84.

Gierańczyk, W., Stańczyk, A. (2001). Okręgi przemysłowe w Polsce u progu XXI wieku [Industrial districts in Poland at the beginning of the 21st century]. Prace Komisji Geografii Przemysłu Polskiego Towarzystwa Geograficznego [Studies of the Industrial Geography Commission of the Polish Geographical Society], 3, 61-69.

Godlewska-Majkowska, H. (2013). Lokalizacja przedsiębiorstw w gospodarce globalnej [Location of enterprises in global economy]. Warszawa: Difin.

Godlewska-Majkowska, H. (2015). Rola ryzyka lokalizacyjnego w kształtowaniu atrakcyjności inwestycyjnej regionów [The role of location risk in shaping the investment attractiveness of regions]. Kwartalnik Nauk o Przedsiębiorstwie, 3, 30-44.

Godlewska-Majkowska, H. (2016). Powiązania strukturalne a podejmowanie decyzji lokalizacyjnych w małych przedsiębiorstwach [Structural Links and Making Location Decisions in Small Enterprises]. Prace Komisji Geografii Przemysłu Polskiego Towarzystwa Geograficznego [Studies of the Industrial Geography Commission of the Polish Geographical Society], 30(1), 47-61.

Grzeszczak, J. (1964). Podstawowe problemy badawcze geografii przemysłu w Polsce [Basic research problems of the geography of industry in Poland]. Biuletyn Komitetu Przestrzennego Zagospodarowania Kraju Polskiej Akademii Nauk, 32.

Grzeszczak, J. (1985). Z badań nad organizacją przestrzenną przemysłu w Polsce (na tle międzynarodowym] [On the research on spatial organisation of industry in Poland (internationally)]. Studia Komisji Przestrzennego Zagospodarowania Kraju Polskiej Akademii Nauk, 5(22), 95-108.

Grzeszczak, J. (1991). Podstawowe orientacje badawcze w geografii przemysłu [Basic research orientations in the geography of research]. Prace Uniwersytetu Adama Mickiewicza, 48, $27-34$. 
Grzeszczak, J. (2011). Osieczna i krajobraz po Osiecznej (w związku z konferencją w sprawie geografii ekonomicznej, 28 XI-1 XII 1955 r.) [Osieczna and the landscape after Osieczna (in connection with the conference on economic geography, 28 XI-1 XII 1955)]. Przeglaqd Geograficzny, 83(4), 557-564.

Gwosdz, K., Micek, G. (2010). Spatial agglomerations in the Polish automotive industry. Przeglad Geograficzny, 82(2), 159-190.

Heder, A., Tkocz, M. (2013). Funkcjonowanie górnictwa węgla kamiennego w gospodarce opartej na wiedzy [The Functioning of Coal Mining in a Knowledge-Based Economy]. Prace Komisji Geografii Przemysłu Polskiego Towarzystwa Geograficznego [Studies of the Industrial Geography Commission of the Polish Geographical Society], 21, 78-93.

Karpiński, A., Paradysz, S., Soroka, P., Żółtkowski, W. (2013). Jak powstawały i jak upadały zakłady przemysłowe $w$ Polsce [How industrial plants in Poland were built and how they fell]. Warszawa: Wydawnictwo Muza SA.

Kieżun, W. (2012). Patologia transformacji [Pathology of transformation]. Warszawa: Wydawnictwo Poltext.

Kilar, W. (2014a). Zmiany potencjału ekonomicznego wybranych korporacji informatycznych $\mathrm{w}$ warunkach kryzysu gospodarczego [Changes in the economic potential of selected information technology corporations in a context of economic crisis]. Prace Komisji Geografii Przemysłu Polskiego Towarzystwa Geograficznego [Studies of the Industrial Geography Commission of the Polish Geographical Society], 27, 57-71.

Kilar, W. (2014b). Spatial Concentration of IT Corporation Headquarters. Prace Komisji Geografii Przemysłu Polskiego Towarzystwa Geograficznego [Studies of the Industrial Geography Commission of the Polish Geographical Society], 25, 56-80.

Kilar, W., Rachwał, T. (2014). Changing Role of Industry in the Economy in the V4 Countries a Regional Approach. 'Club of Economics in Miskolc' Theory, Methodology, Practice, 10(1), 45-54.

Kilar, W., Rachwał, T., Wiedermann, K. (2008). Changes in differentiation of Polish regions' industrial potential within the European Union. In: K. Czapiewski, T. Komornicki (ed.). New functions of rural and industrial space in central and eastern Europe. Warsaw: Institute of Geography and Spatial Organization - Polish Academy of Sciences, Academic Division Polish Geographical Society, 145-158

Komornicki, T. (2006). Eksport w ujęciu regionalnym jako miernik rozwoju przemysłu [Export on a regional basis as a measure of industrial development]. Prace Komisji Geografii Przemysłu Polskiego Towarzystwa Geograficznego [Studies of the Industrial Geography Commission of the Polish Geographical Society], 8, 167-178.

Kortus, B. (1978a). Aktualne kierunki i problemy badawcze geografii przemysłu [Current directions and research problems of the geography of industry]. Kraków: Centralny Ośrodek Metodyczny Studiów Nauczycielskich, Wydawnictwo Naukowe Wyższej Szkoły Pedagogicznej, 14-21.

Kortus, B. (1978b). Nowe tendencje i kierunki w badaniach przestrzennych przemysłu [New tendencies and directions in spatial research of industry]. Folia Geographica. Ser. GeographicaOeconomica, 11.

Kortus, B. (1986). Wstęp do geografii przemysłu [Introduction to the geography of industry]. Warszawa: Wydawnictwo Naukowe PWN.

Kortus, B. (1987). Aktualne kierunki i problemy badawcze geografii przemysłu [Current directions and research problems of the geography of industry]. In: Z. Zioło (ed.). Geografia przemysłu w akademickim kształceniu nauczycieli [Geography of industry in academic teacher education]. Kraków: Wydawnictwo Naukowe Wyższej Szkoły Pedagogicznej w Krakowie.

Kortus, B. (1999). Geografia Przemysłu [Geography of industry]. In: B. Kortus, A. Jackowski, K. Krzemień (ed.). Rozwój i dorobek nauk geograficznych w Uniwersytecie Jagiellońskim 1849-1999 [Development and achievements of geographical sciences at the Jagiellonian University 1849-1999]. Kraków: Instytut Geografii Uniwersytetu Jagiellońskiego, 329-357.

Kuciński, K. (1992). Geografia przemysłu w latach dziewięćdziesiątych (głos w dyskusji) [Geography of industry in the 1990 (voice in the discussion)]. In: Z. Zioło (ed.). Geografia przemysłu $w$ warunkach nowego systemu gospodarowania - problemy badawcze i odzwierciedlenie ich $w$ kształceniu nauczycieli [Geography of industry in the conditions of the new management system - research problems and their reflection in teacher education]. 
Kraków-Warszawa: Centralny Ośrodek Metodyczny Studiów Nauczycielskich, Wyższa Szkoła Pedagogiczna w Krakowie i Komisja Geografii Przemysłu Polskiego Towarzystwa Geograficznego w Warszawie, 246-250.

Kuciński, K. (1998). Szkoła Główna Handlowa jako ośrodek badań przestrzennych przemysłu [Warsaw School of Economics as a Center of Spatial Researches of Industry]. Monografie i Opracowania Szkoły Głównej Handlowej, 434, 7-17.

Kuciński, K. (2001). Lokalizacja przemysłu w nowym systemie ekonomicznym [Industry location in the new economic system]. Materiały i Prace Instytutu Funkcjonowania Gospodarki Narodowej, 76, 7-12.

Kukliński, A. (1964). Kierunki badań nad strukturą przestrzenną przemysłu Polski [Directions of research on the spatial structure of Polish industry]. Biuletyn Komitetu Przestrzennego Zagospodarowania Kraju Polskiej Akademii Nauk, 32.

Kukliński, A. (1976). Problemy przemysłu w systemie studiów regionalnych w Polsce. Uwagi dyskusyjne [Problems of industry in the system of regional studies in Poland. Discussion comments]. Biuletyn Komitetu Przestrzennego Zagospodarowania Kraju Polskiej Akademii Nauk, 93.

Kukliński, A. (1981). Próba oceny roli procesów industrializacji i urbanizacji w kształtowaniu gospodarki przestrzennej [Attempt to assess the role of industrialisation and urbanisation processes in shaping spatial development]. Biuletyn Komitetu Przestrzennego Zagospodarowania Kraju Polskiej Akademii Nauk, 116.

Leszczycki, S., Kukliński, A. (1964). Perspektywy rozwojowe geografii przemysłu w Polsce [The Future Development of Industrial Geography in Poland]. Przegląd Geograficzny, 36(2), 215-225.

Matykowski, R., Tobolska, A. (1994). Przekształcenia społeczno-gospodarcze w Polsce a zróżnicowanie przestrzenne Przemysłu [Socio-economic transformation in Poland and spatial diversification of industry]. In: Z. Zioło (ed.). Zachowania przestrzenne przemysłu w zmieniających się warunkach gospodarowania [Spatial behaviour of industry in changing economic conditions]. Kraków-Warszawa: Komisja Geografii Przemysłu Polskiego Towarzystwa Geograficznego w Warszawie, 79-93.

Micek, G., Gleadle, P., Dawidko, P. (2014). The Role of Institutional Context in the Development of the SME Biotech Sector in Poland. Prace Komisji Geografii Przemysłu Polskiego Towarzystwa Geograficznego [Studies of the Industrial Geography Commission of the Polish Geographical Society], 25, 132-150

Misztal, S. (1997). Rozwój geografii przemysłu i jej problematyki badawczej [Development of the geography of industry and its research issues]. In: B. Domański (ed.). Geografia, Człowiek, Gospodarka [Geography, Man, Economy]. Kraków: Instytut Geografii Uniwersytetu Jagiellońskiego, 115-123.

Misztal, S., Zioło, Z., (1998a). Wprowadzenie [Introduction]. In: S. Misztal, Z. Zioło, Dorobek polskiej geografii przemysłu w badaniach ośrodków akademickich [Achievements of Polish geography of industry in research of academic centers]. Warszawa-Kraków: Polskie Towarzystwo Geograficzne - Komisja Geografii Przemysłu, Instytut Geografii WSP w Krakowie, Wydawnictwo Krakowskiego Oddziału Polskiej Akademii Nauk.

Misztal, S., Zioło, Z. (ed.) (1998b). Dorobek polskiej geografii przemysłu w badaniach ośrodków akademickich [Achievements of Polish geography of industry in research of academic centers]. Warszawa-Kraków: Polskie Towarzystwo Geograficzne - Komisja Geografii Przemysłu, Instytut Geografii WSP w Krakowie, Wydawnictwo Krakowskiego Oddziału Polskiej Akademii Nauk.

Mrozińska, A. (2013). Zmiany strukturalne w przemyśle przetwórczym według województw w latach 1999-2010 [The Structural Changes in the Processing Industry by Voivodeship in the Years 1999-2010]. Prace Komisji Geografii Przemysłu Polskiego Towarzystwa Geograficznego [Studies of the Industrial Geography Commission of the Polish Geographical Society], 21, 157-172.

Pakuła, L. (1978). Problemy teoretyczno-badawcze form koncentracji przestrzennej przemysłu [Theoretical and research problems of forms of spatial concentration of industry]. Folia Geographica, 11, 107-116. 
Pakuła, L. (1983). Próba oceny regionalnych badań przemysłu [Attempt to evaluate regional industry research]. Folia Geographica, 15, 25-37.

Pakuła, L. (2003). Tendencje restrukturyzacji przemysłu Górnośląskiego Okręgu Przemysłowego $\mathrm{w}$ dobie transformacji [Trends in the restructuring of industry in the Upper Silesian Industrial Region in the era of transformation]. Prace Komisji Geografii Przemysłu Polskiego Towarzystwa Geograficznego [Studies of the Industrial Geography Commission of the Polish Geographical Society], 6, 59-66.

Pakuła, L., Troc, M. (1987). Bibliografia przemysłu za lata 1963-1983 [Industry bibliography for the years 1963-1983]. Kraków: Wydawnictwo Naukowe Wyższej Szkoły Pedagogicznej.

Parysek, J.J. (1993). Stare i nowe problemy badawcze geografii Przemysłu [Old and new research problems of the geography of industry]. In: Z. Zioło (ed.). Regionalne problemy uprzemysłowienia [Regional problems of industrialisation]. Kraków: Centralny Ośrodek Metodyczny Studiów Nauczycielskich, Komisja Geografii Przemysłu PTG i Wyższa Szkoła Pedagogiczna w Krakowie, 8-19.

Paszkowski, M. (2008). Kształtująca się gospodarka sieciowa jako pole badawcze geografii [Emerging network economy as a research field of geography of production]. Prace Komisji Geografii Przemysłu Polskiego Towarzystwa Geograficznego [Studies of the Industrial Geography Commission of the Polish Geographical Society], 11, 40-45.

Pączka, S. (1994). Problematyka badawcza zachowań przestrzennych przemysłu w zmieniających się warunkach gospodarowania w Polsce [Research issues of industrial spatial behaviours in changing management conditions in Poland]. In: Z. Zioło (ed.). Zachowania przestrzenne przemysłu $w$ zmieniających się warunkach gospodarowania [Spatial behaviour of industry in changing management conditions]. Kraków-Warszawa: Komisja Geografii Przemysłu Polskiego Towarzystwa Geograficznego w Warszawie, 39-47.

Pukowska-Mitka, M., Tkocz, M. (1992). Restrukturyzacja górnictwa węgla kamiennego w województwie katowickim [Restructuring of coal mining in Katowice Voivodeship]. In: Z. Zioło (ed.). Geografia przemysłu w warunkach nowego systemu gospodarowania-problemy badawcze i odzwierciedlenie ich $w$ kształceniu nauczycieli [Geography of industry under the conditions of the new management system - research problems and their reflection in teacher education]. Kraków-Warszawa: Centralny Ośrodek Metodyczny Studiów Nauczycielskich, Wyższa Szkoła Pedagogiczna w Krakowie i Komisja Geografii Przemysłu PTG w Warszawie, $140-155$.

Rachwał, T. (2001). Funkcjonowanie Krakowskich Zakładów Elektronicznych „TELPOD” w świetle przemian $\mathrm{w}$ polskim przemyśle elektronicznym [Operation of the Krakow Electronic Works „TELPOD” in the light of changes in the Polish electronic industry]. Prace Komisji Geografii Przemysłu Polskiego Towarzystwa Geograficznego [Studies of the Industrial Geography Commission of the Polish Geographical Society], 3, 167-180.

Rachwał, T. (2002). Proces restrukturyzacji przedsiębiorstw przemysłowych Polski PołudniowoWschodniej (na wybranych przykładach) [The process of restructuring industrial enterprises in south-eastern Poland (on selected examples)]. Prace Komisji Geografii Przemysłu Polskiego Towarzystwa Geograficznego [Studies of the Industrial Geography Commission of the Polish Geographical Society], 4, 79-88.

Rachwał, T. (2006). Efekty restrukturyzacji wybranych przedsiębiorstw przemysłowych Polski Południowo-Wschodniej [Effects of restructurings of industrial enterprises in south-east Poland]. Prace Komisji Geografii Przemysłu Polskiego Towarzystwa Geograficznego [Studies of the Industrial Geography Commission of the Polish Geographical Society], 9, 98-115.

Rachwał, T. (2008). Problematyka badawcza funkcjonowania przedsiębiorstw przemysłowych [Research problems concerning the functioning of industrial enterprises]. Prace Komisji Geografii Przemysłu Polskiego Towarzystwa Geograficznego [Studies of the Industrial Geography Commission of the Polish Geographical Society], 11, 53-85.

Rachwał, T. (2009). Changes of industry in the countries of Central and Eastern Europe under conditions of economic transformation and European integration. Geopolitical Studies, 15, 133-164.

Rachwał, T. (2010). Struktura przestrzenna i działowa przemysłu Polski na tle Unii Europejskiej $\mathrm{w}$ dwudziestolecie rozpoczęcia procesów transformacji systemowej [Spatial and division structure of Polish industry against the European Union in the twentieth anniversary of 
the start of the transformation processes]. Prace Komisji Geografii Przemysłu Polskiego Towarzystwa Geograficznego [Studies of the Industrial Geography Commission of the Polish Geographical Society], 16, 105-124.

Rachwał, T. (2011a). Transformations of the employment structure as an expression of the transformation of the Polish industry against the background of the European Union. Bulletin of Geography. Socio-economic Series, 15, 5-25.

Rachwał, T. (2011b). Industrial restructuring in Poland and other European Union states in the era of economic globalization. Procedia. Social and Behavioral Sciences, 19(2011), 1-10.

Rachwał, T. (2011c). Wpływ kryzysu na zmiany produkcji przemysłowej w Polsce [The impact of crisis on changes in industrial production in Poland]. Prace Komisji Geografii Przemystu Polskiego Towarzystwa Geograficznego [Studies of the Industrial Geography Commission of the Polish Geographical Society], 17, 99-113.

Rachwał, T. (2012). Innowacyjność przedsiębiorstw przemysłowych jako czynnik rozwoju miast [Innovativeness of industrial enterprises as a factor of urban development]. Studia Komitetu Przestrzennego Zagospodarowania Kraju Polskiej Akademii Nauk, 141, 135-152.

Rachwał, T. (2013). Rola przedsiębiorstw przemysłowych w rozwoju gospodarki opartej na wiedzy [The Role of Industrial Enterprises in the Development of the Knowledge-Based Economy]. Prace Komisji Geografii Przemysłu Polskiego Towarzystwa Geograficznego [Studies of the Industrial Geography Commission of the Polish Geographical Society], 21, 189-211.

Rachwał, T. (2014). Zmiany strukturalne przemysłu Polski w warunkach kryzysu gospodarczego [Changes in the spatial structure of the Polish industry under economic crisis conditions]. Prace Komisji Geografii Przemysłu Polskiego Towarzystwa Geograficznego [Studies of the Industrial Geography Commission of the Polish Geographical Society], 27, 148-163.

Rachwał, T. (2015a). 30 lat konferencji z zakresu przemian strukturalnych przemysłu i usług oraz 15 lat Prac Komisji Geografii Przemysłu Polskiego Towarzystwa Geograficznego główne problemy badawcze [30 years of the conferences on structural transformation of industry and services and 15 years of the Studies of the Industrial Geography Commission of the Polish Geographical Society - main research issues]. Prace Komisji Geografii Przemysłu Polskiego Towarzystwa Geograficznego [Studies of the Industrial Geography Commission of the Polish Geographical Society], 29(4), 144-160.

Rachwał, T. (2015b). Structural changes in Polish industry after 1989. Geographia Polonica, $88(4), 575-605$.

Rachwał, T., Wiedermann, K. (2008). Multiplier effects in regional development: The case of the motor vehicle industry in Silesian voivodeship (Poland). Quaestiones Geographicae, 27B(1), 67-80.

Rachwał, T., Wiedermann, K. (2015). Industrial and R\&D Activity in Emerging Economies Poland versus other EU Countries. In: Micek, G. (ed.). Understanding Innovation in Emerging Economic Spaces Global and Local Actors. Networks and Embeddedness. Farnham: Ashgate, 33-51.

Rachwał, T., Wiedermann, W., Kilar, W. (2009). Rola przemysłu w gospodarce regionów Unii Europejskiej [The importance of industry in the economy and the regional policy of the European Union]. Prace Komisji Geografii Przemysłu Polskiego Towarzystwa Geograficznego [Studies of the Industrial Geography Commission of the Polish Geographical Society], 14, 31-42.

Raźniak, P., Dorocki, S., Winiarczyk-Raźniak, A. (2018). Eastern European cities as command and control centres in a time of economic crisis. Acta Geographica Slovenica, 58(2), 101-110.

Raźniak, P., Dorocki, S., Winiarczyk-Raźniak, A., Płaziak, M., Szymańska, A. (2016). Lokalizacja ośrodków kontroli i zarządzania elementem stabilności gospodarczej ośrodków miejskich w Europie Środkowo-Wschodniej [Centres of Command and Control Location as an Element of Economic Stability in Urban Centres of Central and Eastern Europe]. Prace Komisji Geografii Przemysłu Polskiego Towarzystwa Geograficznego [Studies of the Industrial Geography Commission of the Polish Geographical Society], 30(2), 38-54.

Rochnowski, H. (1993). Bydgosko-Toruński Okręg Przemysłowy jako przykład okręgu dwubiegunowego [Bydgoszcz-Toruń Industrial District as an example of a bipolar circle]. In: Z. Zioło (ed.). Problematyka Okręgu Przemysłowego w akademickim kształceniu nauczycieli geografii [Problems of the Industrial District in the academic education of geography teachers]. Kraków: 
Centralny Ośrodek Metodyczny Studiów Nauczycielskich, Komisja Geografii Przemysłu Polskiego Towarzystwa Geograficznego, Wyższa Szkoła Pedagogiczna w Krakowie, 79-108. Rutkowska-Gurak, A. (2000). Miejski obszar przemysłowy jako środowisko lokalizacji firm (na przykładzie Służewca Przemysłowego) [Municipal industrial area as a business location environment (on the example of Służewiec Przemysłowy)]. Warszawa: Szkoła Główna Handlowa.

Rydz, E., Jażewicz, I. (1994). Przemiany struktur przestrzenno-gałęziowych przemysłu województwa słupskiego $\mathrm{w}$ zmieniających się warunkach gospodarowania [Transformations of spatial and branch structures of the industry of the Słupsk region in changing farming conditions]. In: Z. Zioło. Zachowania przestrzenne przemysłu $w$ zmieniających się warunkach gospodarowania [Spatial behaviour of the industry in changing economic conditions]. Kraków-Warszawa: Komisja Geografii Przemysłu Polskiego Towarzystwa Geograficznego w Warszawie, 132-144.

Rydz, E., Jażewicz, I. (1997). Procesy transformacji słupskiego ośrodka przemysłowego w latach 1990-1995 [Processes of transformation of the Słupsk industrial center in 1990-1995]. In: Z. Zioło (ed.). Problemy transformacji struktur przemysłowych w procesie przechodzenia do gospodarki rynkowej [Problems of transformation of industrial structures in the process of transition to a market economy]. Kraków-Warszawa: Komisja Geografii Przemysłu Polskiego Towarzystwa Geograficznego w Warszawie i Instytut Geografii Wyższej Szkoły Pedagogicznej w Krakowie, 47-58.

Stachowiak, K. (2008). Podejście instytucjonalne w geografii ekonomicznej i badaniach regionalnych [Institutional approach in economic geography and regional research]. Biuletyn Komitetu Przestrzennego Zagospodarowania Kraju Polskiej Akademii Nauk, 237, 104-128.

Stachowiak, K. (2009). Instytucjonalne uwarunkowania międzynarodowej działalności przedsiębiorstw w Europie Środkowo-Wschodniej [Institutional determinants of international operations of enterprises in Central and Eastern Europe]. In: M. G. Woźniak (ed.). Nierówności społeczne a wzrost gospodarczy: uwarunkowania instytucjonalne [Social inequalities and economic growth: institutional conditions]. Rzeszów: Katedra Teorii Ekonomii i Stosunków Międzynarodowych Uniwersytetu Rzeszowskiego, 165-176.

Stachowiak, K., Stryjakiewicz, T. (2008). Institutional approach in economic geography and its relevance to regional studies. Quaestiones Geographicae, 27B(1), 7-20.

Straszewicz, L. (1987). Geografia przemysłu jako nauka i dyscyplina nauczania [Geography of industry as a science and discipline of teaching]. In: Z. Zioło (ed.). Geografia przemysłu $w$ akademickim kształceniu nauczycieli [Geography of industry in academic teacher education]. Kraków: Centralny Ośrodek Metodyczny Studiów Nauczycielskich, Wyższa Szkoła Pedagogiczna w Krakowie, 8-13.

Stryjakiewicz, T. (1987). Kierunki badawcze geografii przemysłu w Polsce w latach 1945-1980 [Research directions of the geography of industry in Poland in 1945-1980]. In: Geografia przemysłu w akademickim kształcenia nauczycieli [Geography of industry in academic teacher education]. Kraków: Centralny Ośrodek Metodyczny Studiów Nauczycielskich, Wydawnictwo Naukowe Wyższej Szkoły Pedagogicznej w Krakowie, 22-43.

Stryjakiewicz, T. (1992). Ewolucja koncepcji badawczych geografii przemysłu [The evolution of research conceptions of industrial geography]. Współczesne Problemy Geografii Społeczno-Ekonomicznej Polski. Seria Geografia, 55, 163-172.

Stryjakiewicz, T. (1999). Adaptacja przestrzenna przemysłu $w$ Polsce $w$ warunkach transformacji [Spatial adaptation of industry in Poland under transformation conditions]. Poznań: Wydawnictwo Naukowe Uniwersytetu Adama Mickiewicza.

Stryjakiewicz, T. (2001). Koncepcja usieciowienia (networking) w badaniach przestrzenno-ekonomicznych [The concept of networking in spatial and economic research]. In: H. Rogacki (ed.). Koncepcje teoretyczne i metody badań geografii społeczno-ekonomicznej i gospodarki przestrzennej [Theoretical concepts and methods of research on socio-economic geography and spatial management]. Poznań: Bogucki Wydawnictwo Naukowe, 37-47.

Stryjakiewicz, T. (2005a). Sieciowa organizacja gospodarki a rozwój regionalny [Network organisation of economy and regional development]. Biuletyn Komitetu Przestrzennego Zagospodarowania Kraju Polskiej Akademii Nauk, 219, 38-56. 
Stryjakiewicz, T. (2005b). Contrasting Experiences with Business Networking in a Transition Economy: The Case of Poland. In: C.G. Alvstam, E.W. Schamp (ed.). Linking Industries Across the World. Aldershot: Ashgate, 197-219.

Stryjakiewicz, T. (ed.) (2005c). Impact of foreign investors on regional and local development: The case of GlaxoSmithKline Pharmaceuticals S.A. in Poznań. Poznań: Bogucki Wydawnictwo Naukowe.

Stryjakiewicz, T. (2007). Orientacja instytucjonalna w geografii ekonomicznej i jej znaczenie w analizie procesów transformacji struktur przestrzennych [Institutional orientation in economic geography and its importance in the analysis of transformation processes in spatial structures]. In: J. Lach, M. Borowiec, T. Rachwał (ed.). Procesy transformacji społeczno-ekonomicznych i przyrodniczych struktur przestrzennych [Processes of social and economic transformation and natural spatial structures]. Kraków: Wydawnictwo Naukowe Akademii Pedagogicznej, 107-118.

Stryjakiewicz, T. (2009). Lokalizacja firm i zachowania przestrzenne pracowników sektora informatycznego (na przykładzie poznańskiego obszaru metropolitalnego) [Location of companies and spatial behaviour of IT sector employees (on the example of the Poznań metropolitan area)]. Prace Komisji Geografii Przemysłu Polskiego Towarzystwa Geograficznego, 13, 21-33.

Stryjakiewicz, T. (2010). Przemiany w geografii przemysłu [Changes in industrial geography]. Prace Komisji Geografii Przemysłu Polskiego Towarzystwa Geograficznego [Studies of the Industrial Geography Commission of the Polish Geographical Society], 15, 30-44.

Stryjakiewicz, T. (2014). Changes in Polish Industrial Geography at the Turn of the 21st Century. Prace Komisji Geografii Przemysłu Polskiego Towarzystwa Geograficznego [Studies of the Industrial Geography Commission of the Polish Geographical Society], 25, 7-19.

Szajnowska-Wysocka, A. (1990). Bariery rozwojowe ośrodków przemysłowych Górnośląskiego Okręgu Przemysłowego [Development barriers for industrial centers in the Upper Silesian Industrial Region]. In: Z. Zioło. Problematyka ośrodka przemysłowego w akademickim kształceniu nauczycieli Geografii [Problems of the industrial center in the academic education of geography teachers]. Kraków: Centralny Ośrodek Metodyczny Studiów Nauczycielskich, Wyższa Szkoła Pedagogiczna w Krakowie, 65-76

Szejgiec, B., Komornicki, T. (2015). Spatial differentiation of Polish export linkages. Geographia Polonica, 88(1),173-188. DOI: 10.7163/GPol.0011

Ślązak, R. (2016). Czarna księga prywatyzacji 1988-1994, czyli jak likwidowano przemysł [Black book of privatisation 1988-1994, or how the industry was liquidated]. Wrocław: Wektory.

Śleszyński, P. (2007). Gospodarcze funkcje kontrolne w przestrzeni Polski [Economic control functions in the space of Poland]. Prace Geograficzne, 213.

Śleszyński, P. (2008). Duże przedsiębiorstwa w strukturze przestrzennej największych polskich miast [Large enterprises in the spatial structure of the largest Polish cities]. Prace Geograficzne, 217.

Śleszyński, P. (2014). Headquarters of Large Enterprises in the Spatial Structure of Major Polish Cities. Prace Komisji Geografii Przemysłu Polskiego Towarzystwa Geograficznego [Studies of the Industrial Geography Commission of the Polish Geographical Society], 25, 178-193.

Śleszyński, P. (2015). Economic control functions in Poland in 2013. Geographia Polonica, 88(4), 701-708.

Tkocz, M. (2015). Tradycyjny okręg przemysłowy z perspektywy 25-lecia funkcjonowania w gospodarce rynkowej w Polsce. Przykład Górnośląskiego Okręgu Przemysłowego [A traditional industrial district from the perspective of 25 years of functioning in a market economy in Poland. An example of the Upper Silesian Industrial District]. Prace Komisji Geografii Przemysłu Polskiego Towarzystwa Geograficznego [Studies of the Industrial Geography Commission of the Polish Geographical Society], 29(4), 112-126.

Tkocz, M., Sobala, P. (2006). Kapitał zagraniczny w przemianach gospodarczych tradycyjnego ośrodka przemysłowego na przykładzie Chorzowa [Foreign capital in economic changes of a traditional industrial center on the example of Chorzów]. Prace Komisji Geografii Przemysłu Polskiego Towarzystwa Geograficznego [Studies of the Industrial Geography Commission of the Polish Geographical Society], 8, 74-79. 
Tobolska, A. (1997). Przejawy transformacji w przemyśle województwa poznańskiego [Manifestations of transformation in the industry of Poznań Voivodeship]. In: Z. Zioło (ed.). Problemy transformacji struktur przemysłowych $w$ procesie przechodzenia do gospodarki rynkowej [Problems of transformation of industrial structures in the process of transition to a market economy]. Kraków-Warszawa: Komisja Geografii Przemysłu PTG w Warszawie i Instytut Geografii Wyższej Szkoły Pedagogicznej w Krakowie, 129-144

Tobolska, A. (2011). Czynniki lokalizacji fabryk wybranych korporacji międzynarodowych w Polsce [Factors for the location of factories of selected international corporations in Poland]. Rozwój Regionalny i Polityka Regionalna, 15.

Wiedermann, K. (2008). Koncepcja efektów mnożnikowych w wyznaczaniu wpływu przedsiębiorstw na otoczenia [The concept of multiplier effect in determining the influence of enterprises on their socio-economic environment]. Prace Komisji Geografii Przemysłu Polskiego Towarzystwa Geograficznego [Studies of the Industrial Geography Commission of the Polish Geographical Society], 11, 98-106.

Wieloński, A. (2010). Wielkość i struktura eksportu miarą konkurencyjności polskiego przemysłu [Volume and structure of export as a measure of competitiveness of the Polish industry]. Prace Komisji Geografii Przemysłu Polskiego Towarzystwa Geograficznego [Studies of the Industrial Geography Commission of the Polish Geographical Society], 15, 99-104.

Wójtowicz, M. (2017). Rola przemysłu samochodowego w rozwoju społeczno-gospodarczym Meksyku [The role of the automotive industry in the socio-economic development of Mexico]. Prace Komisji Geografii Przemysłu Polskiego Towarzystwa Geograficznego [Studies of the Industrial Geography Commission of the Polish Geographical Society], 31(4), 83-102.

Wójtowicz, M., Rachwał, T. (2014). Globalization and New Centers of Automotive Manufacturing - the Case of Brazil, Mexico, and Central Europe. Prace Komisji Geografii Przemysłu Polskiego Towarzystwa Geograficznego [Studies of the Industrial Geography Commission of the Polish Geographical Society], 25, 81-107.

Wrzosek, S., Zawadzki, M. (ed.) (1974). Planowanie regionalne. Bibliografia piśmiennictwa polskiego 1966-1970, wybór [Regional planning. Bibliography of the Polish literature 1966-1970, selection.] Biuletyn Komitetu Przestrzennego Zagospodarowania Kraju Polskiej Akademii Nauk, 82.

Wrzosek, S., Zawadzki, M. (ed.) (1985). Planowanie regionalne. Bibliografia piśmiennictwa polskiego 1971-1980, cz. I, cz. II. [Regional planning. Bibliography of Polish literature 19711980, part I, cz. II.]. Biuletyn Komitetu Przestrzennego Zagospodarowania Kraju Polskiej Akademii Nauk, 127.

Zawadzki, S. (ed.) (1969). Planowanie regionalne. Bibliografia piśmiennictwa polskiego 19451965 [Regional planning. Bibliography of Polish literature 1945-1965, selection]. Biuletyn Komitetu Przestrzennego Zagospodarowania Kraju Polskiej Akademii Nauk, 55.

Zioło, Z. (1971). Stan badań nad problemem struktury przestrzennej przemysłu i jej form koncentracji [The state of research on the problem of the spatial structure of industry and its forms of concentration]. Materiały Informacyjne WKPG w Rzeszowie, 25-38.

Zioło, Z. (1976). The development of optimum territorial forms of industrial form concentration. Geographia Polonica, 33, 171-182.

Zioło, Z. (1978). Próba konstrukcji teoretycznego modelu okręgu przemysłowego [Attempt to construct a theoretical model of an industrial district]. In: Przemiany społeczno-ekonomiczne Tarnobrzeskiego Rejonu Uprzemysławianego [Socio-economic transformations of the Tarnobrzeg District under Industrialisation]. Warszawa: Polska Akademia Nauk, Komitet Badań Rejonów Uprzemysławianych, Wydawnictwo Naukowe PWN, 25-39.

Zioło, Z. (1987). Próba zarysu teorii struktury przestrzennej przemysłu [An attempt to outline the theory of the spatial structure of industry]. Rocznik Naukowo-Dydaktyczny WSP w Krakowie, $112,103-120$.

Zioło, Z. (1997). Miejsce struktury przestrzennej przemysłu w przestrzeni geograficznej [The place of spatial structure of industry in geographical space]. In: B. Domański (ed.). Geografia, Człowiek, Gospodarka [Geography, Man, Economy]. Kraków: Instytut Geografii Uniwersytetu Jagiellońskiego, 125-132.

Zioło, Z. (2006). Zróżnicowanie światowej przestrzeni przemysłowej w świetle koncentracji siedzib zarządów wiodących korporacji [Diversification of the global industrial space in the light of the concentration of headquarters of leading corporations]. Prace Komisji Geografii 
Przemysłu Polskiego Towarzystwa Geograficznego [Studies of the Industrial Geography Commission of the Polish Geographical Society], 8, 9-26.

Zioło, Z. (2008a). Problemy badawcze struktury przestrzennej przemysłu [Industrial spatial structure: research problems]. Prace Komisji Geografii Przemysłu Polskiego Towarzystwa Geograficznego [Studies of the Industrial Geography Commission of the Polish Geographical Society], 11, 9-25.

Zioło, Z. (2008b). Procesy transformacji przemysłowych układów przestrzennych na tle zmieniającego się otoczenia [Transformational processes in industrial spatial structures in relation to changing surroundings]. Prace Komisji Geografii Przemysłu Polskiego Towarzystwa Geograficznego [Studies of the Industrial Geography Commission of the Polish Geographical Society], 10,11-22.

Zioło, Z. (2012). Miejsce innowacyjności w kształtowaniu procesów rozwoju gospodarczego układów przestrzennych [Position of innovativeness in the processes of economic development of spatial structures]. Prace Komisji Geografii Przemysłu Polskiego Towarzystwa Geograficznego [Studies of the Industrial Geography Commission of the Polish Geographical Society], 20, 9-32.

Zioło, Z. (2014a). Development of Enterprises in the Spatial Structure of Industry (Based on Research of the Industrial Geography Commission of the Polish Geographical Society). Prace Komisji Geografii Przemysłu Polskiego Towarzystwa Geograficznego [Studies of the Industrial Geography Commission of the Polish Geographical Society], 25, 20-37.

Zioło, Z. (2014b). Wpływ kryzysu na kształtowanie struktury przestrzennej przemysłu [Impact of the crisis on the formation of the spatial structure of the industry]. Prace Komisji Geografii Przemysłu Polskiego Towarzystwa Geograficznego [Studies of the Industrial Geography Commission of the Polish Geographical Society], 27, 9-37.

Zioło, Z. (2016). Wpływ uwarunkowań międzynarodowych na rozwój przedsiębiorstw przemysłowych [The Impact of International Determinants on the Development of Industrial Enterprises]. Prace Komisji Geografii Przemysłu Polskiego Towarzystwa Geograficznego [Studies of the Industrial Geography Commission of the Polish Geographical Society], 30(3), 7-24.

Zioło, Z., (2017). Wpływ przemysłu i usług na rozwój społeczno-gospodarczy układów przestrzennych [Impact of Industry and Services on Socio-Economic Development of Spatial Systems]. Prace Komisji Geografii Przemysłu Polskiego Towarzystwa Geograficznego [Studies of the Industrial Geography Commission of the Polish Geographical Society], 31(4), 7-24.

Zioło, Z., Rachwał, T. (ed.) (2006). Międzynarodowe uwarunkowania rozwoju przemysłu [International conditions for the development of industry]. Prace Komisji Geografii Przemysłu Polskiego Towarzystwa Geograficznego [Studies of the Industrial Geography Commission of the Polish Geographical Society], 8.

Zioło, Z., Rachwał, T. (ed.) (2008). Problematyka badawcza geografii przemysłu [Research problems concerning the functioning of industrial enterprises]. Prace Komisji Geografii Przemysłu Polskiego Towarzystwa Geograficznego [Studies of the Industrial Geography Commission of the Polish Geographical Society], 11.

Zioło, Z., Rachwał, T. (2010). Geografia przemysłu i usług [Geography of industry and services]. In: Z. Długosz, Z. Zioło (ed.). Rozwój naukowo-dydaktyczny i kierunki badawcze Instytutu Geografii Uniwersytetu Pedagogicznego im. Komisji Edukacji Narodowej w Krakowie [Scientific and didactic development and research directions of the Institute of Geography of the Pedagogical University of National Education Commission in Krakow]. Kraków: Wydawnictwo Naukowe Uniwersytetu Pedagogicznego, 138-157.

Zioło, Z., Rachwał, T. (ed.) (2011). Wpływ kryzysu na zachowania przedsiębiorstw oraz przemiany struktur regionalnych [The impact of the crisis on the behavior of enterprises and regional structure changes]. Prace Komisji Geografii Przemysłu Polskiego Towarzystwa Geograficznego [Studies of the Industrial Geography Commission of the Polish Geographical Society], 17.

Zioło, Z., Rachwał, T. (ed.) (2013). Funkcje przemysłu i usług w rozwoju gospodarki opartej na wiedzy [Functions of industry and services in the development of knowledge-based economy]. Prace Komisji Geografii Przemysłu Polskiego Towarzystwa Geograficznego [Studies of the Industrial Geography Commission of the Polish Geographical Society], 21. 
Zioło, Z., Rachwał, T. (ed.) (2014). Contemporary issues in Polish Industrial Geography. Prace Komisji Geografii Przemysłu Polskiego Towarzystwa Geograficznego [Studies of the Industrial Geography Commission of the Polish Geographical Society], 25.

Zioło, Z., Rachwał, T. (ed.) (2016a). Międzynarodowe i krajowe uwarunkowania rozwoju przedsiębiorstw [International and national conditions of enterprises development]. Prace Komisji Geografii Przemysłu Polskiego Towarzystwa Geograficznego [Studies of the Industrial Geography Commission of the Polish Geographical Society], 30(1).

Zioło, Z., Rachwał, T. (ed.) (2016b). Międzynarodowe uwarunkowania rozwoju przemysłu [International conditions for the development of industry]. Prace Komisji Geografii Przemysłu Polskiego Towarzystwa Geograficznego [Studies of the Industrial Geography Commission of the Polish Geographical Society], 30(3).

Zioło, Z., Rachwał, T., Kilar, W. (2018). Komisja Geografii Przemysłu [Industrial Geography Commission]. In: M. Sobczyński (ed.). Polskie Towarzystwo Geograficzne w stulecie działalności [Polish Geographical Society on the centenary of activity]. T. 3. Łódź: Polskie Towarzystwo Geograficzne, Wydział Nauk Geograficznych Uniwersytetu Łódzkiego, Katedra Geografii Politycznej, Historycznej i Studiów Regionalnych, 89-132.

Tomasz Rachwal, Ph.D., Head of the Department of Entrepreneurship and Spatial Management, Director of Institute of Geography of the Pedagogical University of Cracow, Rector's Proxy for Entrepreneurship, member of the Senate of the Pedagogical University of Cracow, a Deputy Chair of the Industrial Geography Commission of the Polish Geographical Society, member of the editorial board of several journals, author of textbooks for geography and entrepreneurship. His research interests focus primarily on the issue of change of spatial and branch structures of industry, the determinants for the development of various branches of industrial activity, and the role of manufacturing, selected branches of services and entrepreneurship in local and regional development, as well as geographical and entrepreneurship education.

\section{Address:}

Pedagogical University of Cracow

Institute of Geography

Department of Entrepreneurship and Spatial Management

ul. Podchorążych 2, 30-084 Kraków, Poland

e-mail: Tomasz.Rachwal@up.krakow.pl 